\title{
Coprolite of a durophagous carnivore from the Upper Cretaceous Godula Beds, Outer Western Carpathians, Poland
}

\author{
Piotr BAJDEK ${ }^{1, *}$ \\ 1 Aleja Najświętszej Maryi Panny 20/20A, 42-200 Częstochowa, Poland
}

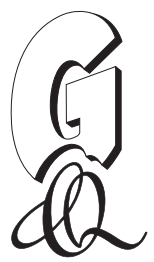

\begin{abstract}
Bajdek P. (2013) Coprolite of a durophagous carnivore from the Upper Cretaceous Godula Beds, Outer Western Carpathians, Poland. Geological Quarterly, 57 (2): 361-364, doi: 10.7306/gq.1094

The Upper Cretaceous turbidite sandstones of the Godula Beds at Miedzybrodzie Bialskie, Outer Western Carpathians, Poland, yielded a specimen here interpreted as a coprolite due to its elongated morphology and a high content of fragmented inoceramid shells. The coprolite was produced by a durophagous carnivore, which was most likely a teleost fish, or possibly a reptile. Coprolites are therefore confirmed to have a potential utility as aggregations of body fossils in macrofossil-poor sedimentary rocks, exemplified by the Godula Beds.
\end{abstract}

Key words: coprolite, feces content, taphonomy, turbidite sandstone, Cretaceous.

INTRODUCTION

Fossil feces are a precious source of information about ecology of extinct animals and ancient ecosystems (Thulborn, 1991; Hunt et al., 1994). Coprolites have been described from various types of sedimentary rocks formed in both marine and non-marine environments during the Phanerozoic (Hunt et al., 1994; Hunt and Lucas, 2005). Cretaceous marine siliciclastic sediments have already yielded some vertebrate coprolites (Chin et al., 2008; Eriksson et al., 2011; Mahaney et al., 2012). For example, Souto and Schwanke (2010) described two vertebrate coprolites from turbidite sandstones of the Lower Cretaceous Maceió Formation, Brazil, formed during a marine transgression. Here, I describe a putative vertebrate coprolite from a marine deep-water turbidite sandstone.

\section{GEOLOGICAL SETTING}

The specimen described here comes from the Miedzybrodzie Bialskie village, located $10 \mathrm{~km}$ to the south-east of Bielsko-Biała and $12 \mathrm{~km}$ to the north of Żywiec in the Outer Western Carpathian Mountains, southern Poland (Fig. 1). It was found by Dawid Mazurek (Polish Academy of Sciences) in an exposure on the shore of the Międzybrodzkie Lake (Fig. 1C). The rocks exposed at the site are interbedded gray sandstones

*E-mail: piotr.bajdek@gmail.com

Received: December 19, 2012; accepted: February 14, 2013; first published online: May 15, 2013 and gray shales representing the Godula Beds of the Carpathian flysch.

The Godula Beds were deposited in the Silesian Basin (northern Tethys) at the foot of the northern slope of the Silesian Ridge in a marine deep-water shifting system of fans and aprons dominated by turbidity currents (Słomka and Słomka, 2001, 2005; Bębenek, 2011). The deposition of the flysch series in the Silesian Basin lasted from the Cenomanian to the Oligocene - Early Miocene (Cieszkowski et al., 2006; Doktor et al., 2010; Bębenek, 2011). The Godula Beds are dated biostratigraphically based on foraminiferan microfossils, however, the precise age range of the beds is problematic and diachronic (see, Lemańska, 2005). They are generally thought to be Turonian-Lower Senonian (Słomka and Słomka, 2001; Bębenek, 2011) and their formation took about 10 million years (Słomka and Słomka, 2001), perhaps until the Campanian (Lemańska, 2005). The foraminiferal assemblages from the Godula Beds suggest that the beds were formed below the CCD in low oxygen and high energy conditions with a relatively high flux of organic matter (Lemańska, 2005).

The bottom surfaces of the sandstone beds at the site in Międzybrodzie Bialskie are covered by hieroglyphs and abundant, but mostly simple morphologically ichnofossils. Ichnofossils of the Godula Beds vary with lithofacies (Skupien et al., 2009). The shale beds contain the ichogenera Planolites, Thalassinoides and Chondrites, whereas within the sandstone beds there are such ichnogenera as Arthrophycus, Helminthopsis, Ophiomorphaand Planolites (Skupien et al., 2009).

\section{SPECIMEN DESCRIPTION}

The specimen is stored in the Institute of Paleobiology, Polish Academy of Sciences, Warszawa and cataloged as ZPAL Tf.6. It is approx. $15 \mathrm{~cm}$ long, max. $2.6 \mathrm{~cm}$ wide, longitudinally 


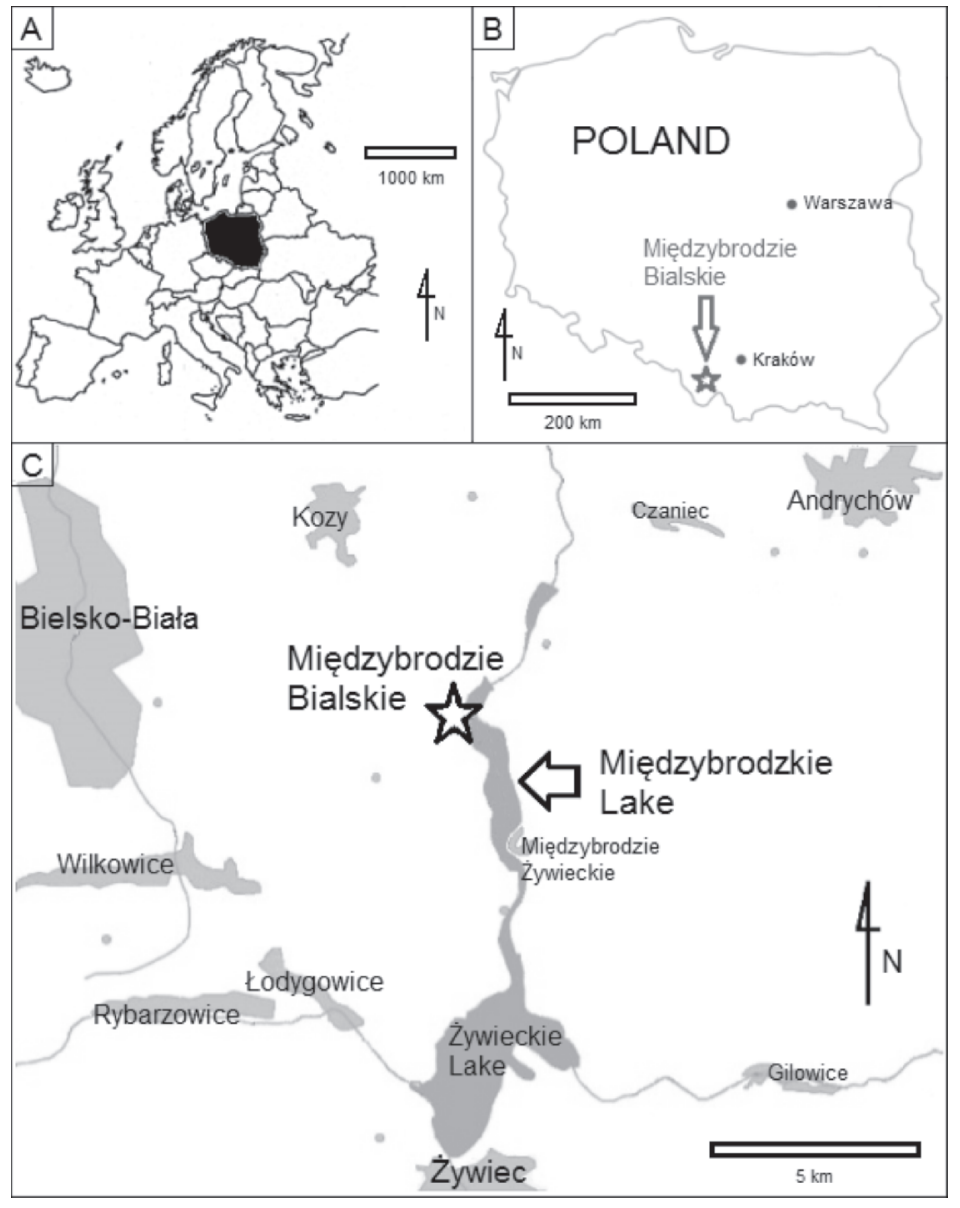

Fig. 1. Map showing the location of the Międzybrodzie Bialskie site

A - Europe with Poland in black, B - site in Poland, C - Międzybrodzie Bialskie village and the Międzybrodzkie Lake marked on a map of the region amorphous matrix texture. It is difficult to explain the origin of this nodule by other biological, sedimentary or diagenetic processes. The groundmass texture of a coprolite is often amorphous and droppings tend to lie in the substrate in a stable position (Thulborn, 1991). These features can be useful in distinguishing coprolites from most of inorganic concretions and nodules as well as from other trace fossils, as sediment-filled burrows. It is supported by the high content and fragmentation of organic remains, that are characteristic for feces (Hunt et al., 1994).

Body fossils are extremely rare in the host sandstones (D. Mazurek pers. comm., 2013). Although foraminiferan microfossils are well-known (Lemańska, 2005; Szydło et al., 2007), most of the studied literature lacks information about body macrofossils from the Godula Beds (e.g., Cieszkowski, 2004; Słomka and Słomka, 2005; Cieszkowski et al., 2006; Bębenek, 2011). The general rarity of body macrofossils in the host rocks can be explained by (a) their deposition close to the CCD, (b) low oxygen conditions, (c) the harsh high energy environment and (d) the sedimentologic mechanism. Inoceramids have been, however, mentioned from the Godula Beds, e.g., by Bieda et al. (1963).

Fossil feces are sometimes a unique source of body fossils which otherwise would be missing or difficult to collect from the host sediments. This may be explained by:

- specific microenvironment and fossilization conditions within feces; for example, Chin et al. (2003) described fossilized muscle tissue within a Cretaceous coprolite;

- transport in the gastrointestinal tract of the producer far away from the place where the food components were consumed and/or selective accumulation and aggregation as food ingredients.

slightly wriggled in shape and progressively narrowed toward one end (Fig. 2). In cross-section the specimen is oval, approx. $2 / 3$ as high as wide (Fig. $2 \mathrm{C}$ ). It is exposed on the bottom surface of a sandstone block.

The specimen contains a significant amount of shell fragments of inoceramids ranging from $0.5 \mathrm{~mm}$ up to $2.3 \mathrm{~cm}$ in length (Fig. 2B arrows; Figs. 3C and 4). At least 17 separate shell fragments were observed both on the surface and inside the specimen. The shells are oriented chaotically, often perpendicularly to the bedding and the largest ones are arranged lengthwise in the specimen. The coprolite is almost entirely composed of the same rock type as the host rock, which is a very finely grained sandstone; a siltstone fragment is also present in the specimen (Fig. 3). Reddish oxides are best visible on the surfaces of the specimen and in the host rock's cracks.

\section{INTERPRETATION AND DISCUSSION}

\section{TAPHONOMIC ANALYSIS}

The specimen is interpreted as a coprolite due to its (a) elongated shape and three-dimensional morphology, (b) parallel orientation to the bedding, (d) content composed of fragmented bivalve shells, (e) chaotic orientation of the shells, i.e.

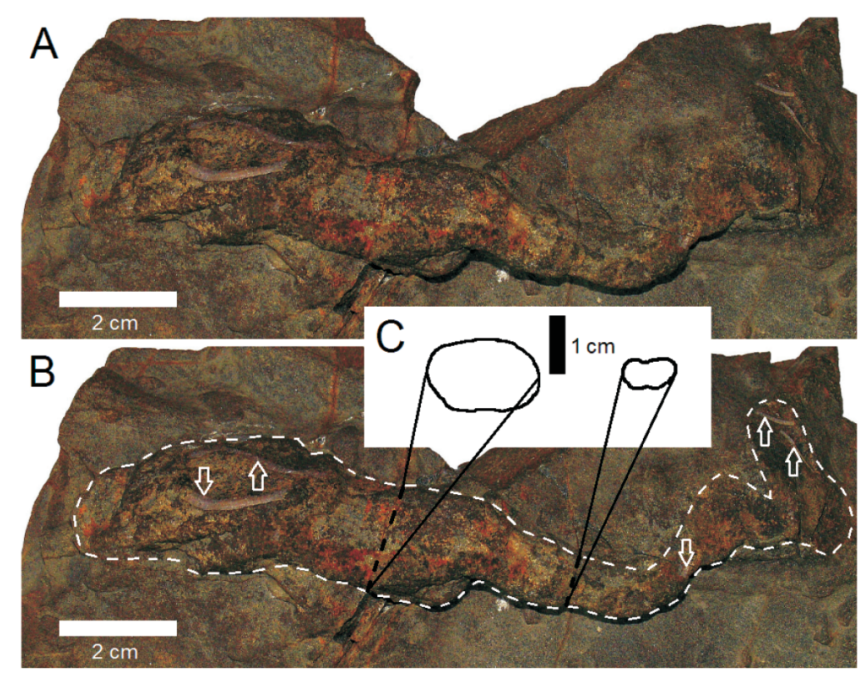

Fig. 2. Coprolite specimen ZPAL Tf.6

A - entire specimen exposed on a sandstone block; $\mathbf{B}$ - contours of the specimen (white intermittent line) and some shell fragments (white arrows); $\mathbf{C}$-cross-sections of the specimen (corresponding to the black intermittent lines in the Fig. 2B) 


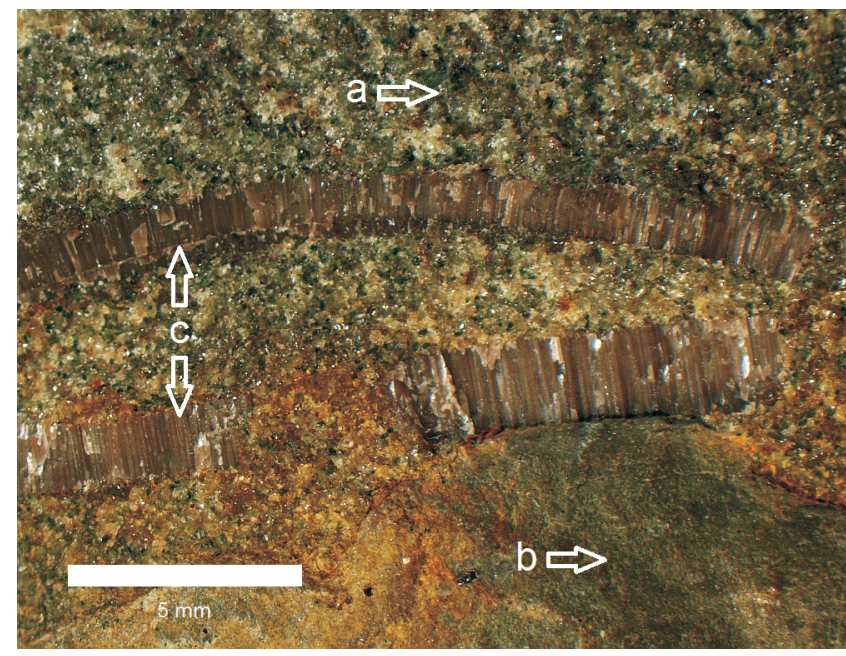

Fig. 3. The interior of ZPAL Tf.6 photographed under the stereoscope microscope Olympus SZX10 equipped with the camera Olympus E-510

The specimen is broken in several separate fragments; weathered external as well as freshly exposed internal surfaces were examined; a - very fine grained sandstone, b - siltstone, c - shell fragments

These two mechanisms may co-occur. Yates et al. (2012) described the earliest post-Paleozoic freshwater bivalves as a content of coprolites suggesting that the thin shells have been preserved due to the specific microenvironment within the feces, whereas the surrounding siliciclastic sediments contained no shells. However, calcitic shells usually have a good fossilization potential (unless below the CCD) and no exceptional diagenetic conditions can be deduced from the coprolite from the Godula Beds. Moreover, although body macrofossils are rare in the Godula Beds, bivalve shells had been already reported. This all suggests that the coprolite at hand should be interpreted basically as a simple aggregation of food ingredients
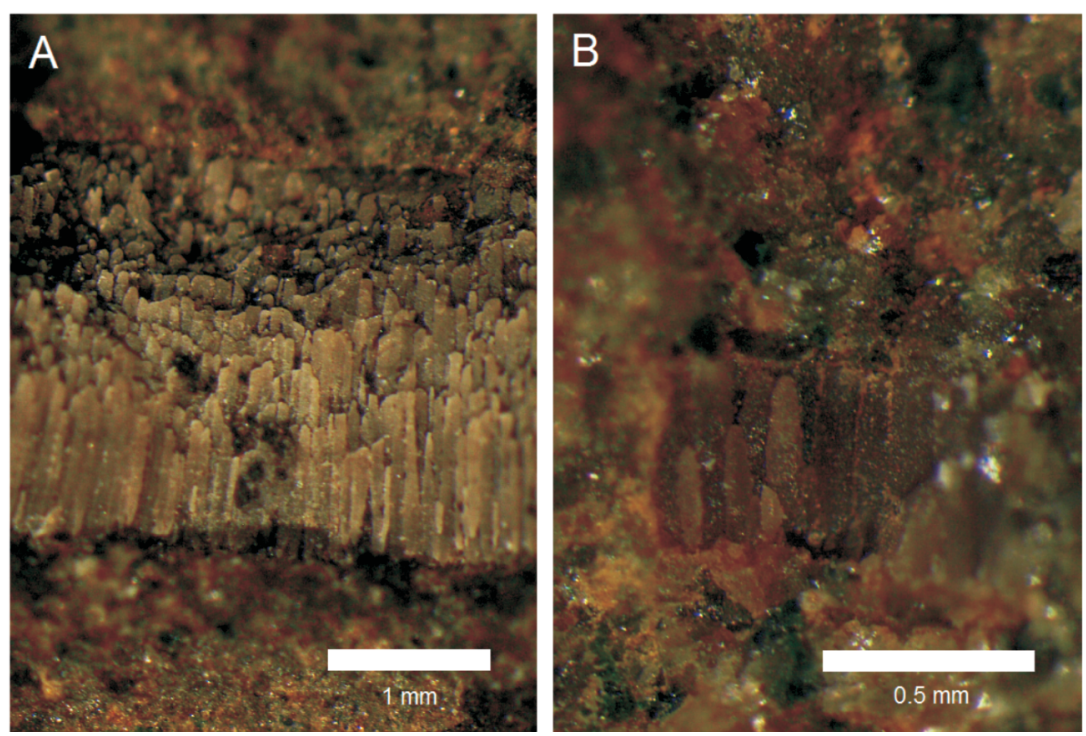

Fig. 4. Inoceramid shells in the coprolite specimen ZPAL Tf.6 under a stereoscope microscope

A - weathered shell exposed on the specimen surface; B - small shell fragment inside the specimen rather than a case of an exceptional preservation in a specific microenvironment.

Feces as humpback whale droppings may be able to float on the ocean surface (Kieckhefer, 1992). However, a remote transport of the specimen at hand seems not probable, because:

- it is graceful in morphology and potentially delicate;

- rapid burial is often crucial for preservation of feces (e.g., Chin et al., 2003; Eriksson et al., 2011);

- it was made by an animal which fed on benthic fauna in a deep-water environment - floating feces on the sea surface would be more expected if produced by nektonic animals feeding mostly near the water surface.

The specimen is exposed on the bottom surface of a sandstone bed. The feces were hypothetically produced close to the place of its discovery, and then buried by sediments of a turbidity current, rather than transported by the current. The fecal mass was substituted by siliciclastic material only preserving the original morphology of the feces and the content of calcite shell fragments.

\section{REMARKS ON PALAEOBIOLOGY}

Coprolite content reflects the diet of its producer (Hunt et al., 1994). However, digested diet components may vary significantly in both resistance for dissolution by stomach acids and their fossilization potential after leaving the gastrointestinal tract. For example, Sato and Tanabe (1998) described a supposed stomach content of a Cretaceous short-necked plesiosaur that included a large number of isolated calcite ammonoid jaws, but low-resistant aragonite ammonoid shells were missing. Because only the robust calcite shells preserved in the coprolite studied here are relatively resistant, conclusions about the diet and habit of its producer may be misleading. It is difficult to rule out the simple possibility that remains of other species included in the diet have been completely dissolved. Nevertheless, the content of inoceramid shells is quite significant in this coprolite, suggesting that its producer at least partially fed on such benthic molluscs and had a good capacity of crushing sturdy shells. It moreover suggests that the source animal was a durophagous carnivore.

This coprolite seems too large to have been produced by an invertebrate, perhaps except by a large cephalopod. Among aquatic vertebrates both fishes and reptiles were potentially capable to produce feces of this diameter and volume. Because sharks and other groups of fishes including basal actinopterygians produce feces of spiral morphologies (Jain, 1983; Gilmore, 1992), the producer might be a teleost fish which lack the spiral intestinal valve, or a reptile. Non-spiral fossil feces of fishes and tetrapods may be difficult to distinguish between each other (Hunt et al., 1994).

A single probable actinopterygian scale was found in the host rocks at the site (D. Mazurek pers. comm., 2013). Moreover, inoceramid shells were described from stomach contents and coprolites of sea turtles from the Upper Albian )Toolebuc Formation, Australia (Kear, 2006). Modern sea turtles may feed on nektonic and benthic fauna in 
depths of several hundred of metres below the water surface in full marine ecosystems, even reaching 1200 meters of depth (Spotila, 2004). However, the protostegid turtle stomach contents described by Kear (2006) come from a shallow sea environment ( $<100 \mathrm{~m}$ depth). Although both fishes and reptiles could potentially produce this coprolite based on the morphology of the specimen and its content, a fish seems a more probable producer.

\section{CONCLUSIONS}

The examined specimen from the Upper Cretaceous sandstones of the Godula Beds is interpreted as a coprolite produced by a durophagous carnivore, which was probably a tele- ost fish, or possibly a reptile. It was most likely produced close to the place of its discovery and buried beneath sediments from a turbidity current. Although body macrofossils are rare in the Godula Beds, coprolites have a potential utility as a source of such fossils in these and supposedly in some other fossil-poor sedimentary rocks.

Acknowledgments. I am grateful to D. Mazurek (Polish Academy of Sciences) for making the specimen available for this study. I thank A. Halamski (the Curator of the Collection of the Institute of Paleobiology, Polish Academy of Sciences) for help. I thank Prof. A. Ślączka and an anonymous journal reviewer for helpful comments and corrections which allowed me to improve this paper. I also thank M. Tałanda (University of Warsaw) and M. Trzepizur (Częstochowa, Poland) for the technical assistance.

\section{REFERENCES}

Bębenek S. (2011) Typy sedymentacji utworów silikoklastycznych serii śląskiej Zewnętrznych Karpat fliszowych walorem poznawczym i geoturystycznym Beskidu Małego. PhD thesis. AGH University of Science and Technology, Faculty of Geology Geophysics and Environmental Protection, Kraków.

Bieda F., Geroch S., Koszarski L., Książkiewicz M., Żytko K. (1963) Stratigraphie des Karpates Externes Polonaises. Biuletyn Instytutu Geologicznego, 181.

Chin K., Eberth D.A., Schweitzer M.H., Rando T.A., Sloboda W.J., Horner J.R. (2003) Remarkable preservation of undigested muscle tissue within a Late Cretaceous tyrannosaurid coprolite from Alberta, Canada. Palaios, 18: 286-294.

Chin K., Bloch J., Sweet A., Tweet J., Eberle J., Cumbaa S., Witkowski J., Harwood D. (2008) Life in a temperate Polar sea: a unique taphonomic window on the structure of a Late Cretaceous Arctic marine ecosystem. Proceedings of the Royal Society B, 275: 2675-2685.

Cieszkowski M. (2004) Stops 3-4: Ustroń, Brenna. Special Papers of the Mineralogical Society of Poland, 24: 427-428.

Cieszkowski M., Golonka J., Waśkowska-Oliwa A., Chrustek M. (2006) Geological structure of the Sucha Beskidzka-Świnna Poręba region (Polish Flysch Carpathians) (in Polish with English abstract). Geologia, 32: 155-201.

Doktor M., Golonka J., Waśkowska A., Słomka T. (2010) The best geotouristic objects of the Silesian Unit, Outer Flysch Carpathians in the vicinity of Krakow, Poland. Geologica Balcanica, 39: 459-466.

Eriksson M.E., Lindgren J., Chin K., MDnsby U. (2011) Coprolite morphotypes from the Upper Cretaceous of Sweden: novel views on an ancient ecosystem and implications for coprolite taphonomy. Lethaia, doi: 10.1111/j.1502-3931.2010.00257.x

Gilmore B. (1992) Scroll coprolites from the Silurian of Ireland and the feeding of early vertebrates. Palaeontology, 35: 319-333.

Hunt A.P., Lucas S.G. (2005) A non marine vertebrate coprolite acme zone in the Permo-Triassic. New Mexico Museum of Natural History and Science Bulletin, 30: 123-124.

Hunt A.P., Chin K., Lockley M.G. (1994) The paleobiology of vertebrate coprolites. In: The Paleobiology of Trace Fossils (ed. S.K. Donovan): 221-240. John Wiley, London.

Jain S.L. (1983) Spirally coiled "coprolites" from the Upper Triassic Maleri Formation, India. Palaeontology, 26: 813-829.

Kear B.P. (2006) First gut contents in a Cretaceous sea turtle. Biology Letters, 2: 113-115.

Kieckhefer T.R. (1992). Feeding ecology of humpback whales in continental shelf waters near Cordell Bank, California. MSc Thesis. San Jose State University, San Jose.
Lemańska A. (2005) Comparison of deep-water agglutinated foraminifera from the hemipelagic variegated shales (Lower Turonian-Lower Santonian) and the turbiditic Godula beds (Upper Santonian-Campanian) in the Lanckorona-Wadowice area (Silesian Unit, Outer Carpathians, Poland). Studia Geologica Polonica, 124: 259-272.

Mahaney W.C., Barendregt R.W., Allen C.C.R., Milner M.W., Bray D. (2012) Coprolites from the Cretaceous Bearpaw Formation of Saskatchewan. Cretaceous Research, http://dx.doi.org/10.1016/j.cretres.2012.10.005

Sato T., Tanabe K. (1998) Cretaceous plesiosaurs ate ammonites. Nature, 394: 629-630.

Skupien P., Rubík M., Švábenická L., Mikuláš R., Vašíček Z., Matýsek D. (2009) Cretaceous oceanic red beds in the Outer Western Carpathians, Czech Republic. SEPM Special Publication, 91: 99-109.

Słomka T., Słomka E. (2001) Sequences of the lithofacies and depositional intervals in the Godula Beds of the Polish Outer Carpathians. Annales Societatis Geologorum Poloniae, 71: $35-42$.

Słomka T., Słomka E. (2005) The Godula beds in the quarry in Bielsko-Straconka (in Polish and English summary). In: Katalog Obiektów Geoturystycznych w Polsce: 182-183. Ministry of the Environment. http://www.mos.gov.pl/g2/big/2009_06/da0705fa$-14 \mathrm{e} 2050906358 \mathrm{f} 4 \mathrm{~d} 801 \mathrm{a} 48 \mathrm{ff} 6 . \mathrm{pdf}$

Souto P.R.F., Schwanke C. (2010) Presence of vertebrate coprolites from the Alagoas Basin, Lower Cretaceous (in Portuguese with English summary). Boletim do Museu Paraense Emílio Goeldi CiLncias Naturais, 5: 189-194.

Spotila J.R. (2004) Sea Turtles: a Complete Guide to their Biology, Behavior, and Conservation. Johns Hopkins University Press, Baltimore.

Szydło A., Malata T., Nescieruk P. (2007) Tafonomia otwornic w kontekście rozwoju środkowokredowej sedymentacji w strefie śląsko-podśląskiej (polskie Karpaty Zewnętrzne). "Granice Paleontologii" XX Konferencja Naukowa Paleobiologów i Biostratygrafów Polskiego Towarzystwa Geologicznego. Book of Abstracts: 135-136. http://www.phacops.pl/pub/documents/34_granice_paleontologii.pdf

Thulborn R.A. (1991) Morphology, preservation and palaeobiological significance of dinosaur coprolites. Palaeogeography, Palaeclimatology, Palaeoecology, 83: 341-366.

Yates A.M., Neumann F.H., Hancox P.J. (2012) The Earliest Post-Paleozoic freshwatar bivalves preserved in coprolites from the Karoo Basin, South Africa. PLoS ONE, 7 (2): e30228. doi:10.1371/journal.pone.0030228 